\title{
Arguing against security communitarianism
}

\section{Pinar Bilgin}

To cite this article: Pinar Bilgin (2015) Arguing against security communitarianism, Critical Studies on Security, 3:2, 176-181, DOI: 10.1080/21624887.2015.1065117

To link to this article: https://doi.org/10.1080/21624887.2015.1065117

曲 Published online: 02 Sep 2015.

Submit your article to this journal

山ll Article views: 174

Q View related articles $\sqsubset$

View Crossmark data \lceil

Citing articles: 1 View citing articles $\asymp$ 


\title{
Arguing against security communitarianism
}

\author{
Pinar Bilgin* \\ Department of International Relations, Bilkent University, Ankara, Turkey
}

\begin{abstract}
Anthony Burke's 'security cosmopolitanism' is a fresh and thought-provoking contribution to critical theorizing about security. In this discussion piece, I would like to join Burke's call for 'security cosmopolitanism' by way of arguing against 'security communitarianism'. I understand the latter as a particular approach that seeks to limit the scope of security to one's community - be it the 'nation-state' or 'civilization'. I will suggest that arguing against 'security communitarianism' requires paying further attention to the postcolonial critique of cosmopolitanism.
\end{abstract}

Keywords: security; cosmopolitanism; postcolonial; critical security studies

Anthony Burke's (2013) 'security cosmopolitanism' is a fresh and thought-provoking contribution to critical theorizing about security. This is an approach that Burke has developed over the years through his analysis of the (re)production of Australia's 'invasion anxiety' as a technique of governance in Fear of Security (Burke 2001), and his elaborate considerations on ways of seeking security with and not against others in Beyond Security Ethics and Violence: War against the Other (2007). A number of issues have already been highlighted in the first round of responses to Burke's 2013 article. In this discussion piece, I would like to join Burke's call for 'security cosmopolitanism' by way of arguing against 'security communitarianism'. I understand the latter as a particular approach that seeks to limit the scope of security to one's community - be it the 'nation-state' or 'civilization'. I will suggest that arguing against 'security communitarianism' requires paying further attention to the postcolonial critique of cosmopolitanism.

\section{Burke's security cosmopolitanism}

The cosmopolitan aspect of Burke's approach emerges especially when arguing against those who want to limit the scope of security to their immediate community. The author draws upon a number of schools of critical theorizing about violence, war, and security - but without aligning with any of them too closely. More specifically, Burke taps into English school theorizing on the necessity of norms and cautious solidarism in the international arena (Wheeler 2000); Aberystwyth school's emancipatory approach to security theorizing (Booth 2007; Walker 1997); and post-structuralist sensibilities regarding the (re)production of boundaries and insecurities through practices of security (Bigo 2001). Yet Burke's 'security cosmopolitanism' does not sit comfortably with any of these approaches insofar as he underscores the pertinence of post-structuralist critique about boundaries and in/security while advancing an explicitly normative agenda on global security.

*Email: pbilgin@bilkent.edu.tr 
Stated in terms of his affinities with other critical approaches to security theorizing, Burke underscores Vivien Jabri's $(2007,2013)$ critique regarding the limits of liberal cosmopolitanism as security governance. Yet while Jabri calls for 'cosmopolitan solidarity' as a solution, Burke wants to retain both 'cosmopolitanism' and 'security' while theorizing differently about both. In doing so, Burke aligns his thinking with Ken Booth's (2007) emphasis on the politics of security and the need for an emancipatory approach to security theorizing. Yet, at the same time, Burke $(2013,5)$ seeks to push Booth's emancipatory approach to security further, by underscoring post-structuralist sensibilities regarding 'security as a set of promises and dangers'. As such, Burke advances an explicitly normative agenda on global security, and offers a much-needed corrective to some strands of critical theorizing that do not cross boundaries of their schools even as they seek to rethink the relationship between boundaries and security.

\section{Against security communitarianism}

In arguing against security communitarianism, I draw upon postcolonial scholars' critique of liberal cosmopolitanism having a 'dark side' (Rao 2010; also see Grovogui 2005), understood as injustices and violence that have been committed in the name of 'cosmopolitanism'. It is also for this reason that Jabri (2007) makes a case for 'cosmopolitan solidarity' and not 'cosmopolitan security'. Her objection is not only to 'security' as a technique of governance (as Burke also notes), but also to particular understandings and practices of liberal cosmopolitanism that have been complicit in legitimating and maintaining exclusionary practices toward the postcolonial (which Burke did not address in the 2013 piece; but see: Burke 2008).

My drawing on the postcolonial critique to join Burke's security cosmopolitanism may come across as counterintuitive. This is because postcolonial interrogations of the 'dark side' of liberal cosmopolitanism are sometimes marshaled to warrant communitarian approaches to security - more specifically, when seeking to give primacy to 'culturalist' approaches to security in/of one's own community (be it 'nation-state' or 'civilization') against the more emancipatory approaches to security (see, for example, Ayoob 1997). In those instances, critiquing the particularity of some forms of universalism is conflated with critiquing the universals - as with criticisms regarding the particularity of prevailing notions of 'human rights' being conflated with criticisms of the notion of universal human rights. Such conflation is then used as a stepping-stone to make a case for 'lighter' human rights regimes - as with the 1990s debates on 'Asian values' or the 2000s debates on 'Dialogue of Civilizations' (on 'Asian values', see, Burke 2007, ch. 4; on 'Dialogue of Civilizations', see, Bilgin 2012, 2014). In contrast, security cosmopolitanism seeks to counter both the liberal cosmopolitan and 'culturalist' communitarian approaches to security.

That said, the postcolonial critique does not warrant security communitarianism (also see Rao 2010; Grovogui 2005), not least because the latter goes against the humanist sensibilities that have shaped the former (see, for example, Said 2003). Viewing the postcolonial critique as warranting communitarianism also underestimates the contributions of postcolonial scholars to critical theorizing about the universals (Krishna 1993; Grovogui 2005, 2006b, 2011b). Indeed, postcolonial scholars' contributions to debates on human rights resist those attempts to limit the scope of security to one's own community on such 'culturalist' grounds. Rather, the postcolonial critique could be better understood as conditioned by the historical legacy of liberal cosmopolitanism and the practices of those who have hesitated to broaden the scope of security beyond their immediate community even when acting in the name of liberal cosmopolitanism (Grovogui 2011a). What follows looks at three major issues identified by the postcolonial critics by focusing on the 'human rights' debates. 
To begin with, cosmopolitan approaches are often criticized for seeking to impose 'universally' what are 'particular' definitions of 'human rights'. Such criticisms of the particularity of universals, however, need not be taken as a rejection of universals as it is sometimes suggested. Consider Chris Brown $(1988,342)$, who maintains that the fact that human rights notions were learned either 'by direct intervention or by creating a situation which ensured that the only way to resist direct intervention was to adopt Western ways' should serve as a reminder that they are, in fact, not universal. On the one hand, Brown's reminder about colonial encounters through which such universals have been produced is pertinent and constitutes an instance of reflection on the nature of the particularity of liberal universalism. On the other hand, Brown's assumption that colonial encounters only shaped the colonized but not the colonizer does not allow developing a fuller critique of the nature of the particularity of liberal cosmopolitanism. When the critics point to the 'particular' framework within which prevalent conceptions of human rights have come about, they are pointing to the ways in which that framework has been 'constituted by the particular and by the exclusion of other particulars' (Bhambra and Shilliam 2009, 7). Such criticism should not be conflated with those proponents of 'Asian values' who seek to '[revive] pre-Western social forms' that Brown $(1988,342)$ is critical of. This is not only because of the impossibility of such a recovery, as Brown also highlights, but mostly because what the postcolonial critics are concerned about is not the notion of universals, but the practice of applying particular universals without reflecting on their particularity, and without thinking about ways of making them less exclusionary (Grovogui 2005, 2011b).

A second related problem that the critics have identified with cosmopolitan approaches is their lack of reflection on the ways in which universals have been applied arbitrarily, thereby resulting in an erosion of trust among peoples regarding concrete instantiation of such universals (Rao 2010). Responding to Andrew Linklater's (1998) call for extending the moral boundaries of political community to include those who were previously excluded, Siba Grovogui writes:

Linklater's generosity assumes full knowledge of postcolonial criticism of the problems of international politics. But he is mistaken about related criticisms of modernity, rationalism, and philosophical and political universalism. Such criticisms do not conceive prior misapplication or suspension of international morality (likened metonymically to a liberal constitutional regime) as a mere problem of exclusion. They involve considerations of the very terms of the constitutional order - the implicated political imaginaries, juridical and moral systems, and their base-notions of communities and obligations - as mechanisms of exclusion. (Grovogui 2006a, 48-49)

Beate Jahn $(1998,631)$ reminds that thinkers such as Samuel von Pufendorf and Emmerich de Vattel, whose writings Linklater has built upon, 'did not develop universal ideas but rather universal yardsticks which were supposed to provide them with a justification not to extend equal rights to others'. Accordingly, argues Jahn, Linklater's model excludes others at the moment of inclusion:

For it is on the basis of the 'inclusion' into humanity defined as European rationality, European political organization, European capitalism or forms of communication and morality that alternative forms of rationality, political organization, modes of production or forms of communication and morality are excluded, not only form the higher echelons of humanity, but also from certain concrete legal and moral rights. (Jahn 1998, 636-7)

Put differently, what the critics consider problematic about liberal cosmopolitanism is not only that particular universals are imposed in seeking to 'better' human condition in 
different parts of the world, but also that such universals have been imposed arbitrarily, and that the proponents of liberal cosmopolitanism in IR have had precious little to say about that (Grovogui 2005, 2006b, 2011b).

A third problem that the postcolonial critics identify with liberal cosmopolitanism is that universals are portrayed as having a single (Western) origin, thereby overlooking others' contributions and contestations. One way of rendering prevalent notions of human rights less exclusionary would be, the critics noted, to problematize assumptions regarding 'Western' origins of human rights (Bhambra and Shilliam 2009) and the assumption that ideas have a single origin as opposed to multiple 'beginnings' (Said 1975; also see Krishna 1993).

Highlighting the need to distinguish between 'establishing the "origins of Western notions" and "Western origins" of human rights', Grovogui (2011b, 43) reminded that the former allows us to understand the nature of the particularity of prevalent human rights notions. The latter, in turn, rests on Eurocentric assumptions that 'self-consciously or not. . .appropriate the human genius for "Europe" or the "West" thereby overlooking others' contributions to and contestations of what are portrayed as 'Western' ideas (Grovogui 2006a, 4). Critiquing the latter, Grovogui writes:

To be sure, social and critical theorists are cognizant of temporal and spatial intellectual pluralism and the hybridity and the fluidity of ideas and institutions. But they assume Western origination of crucial ones. By implication, the methods and canons of analysis necessarily remain 'Western' while the antiseptic gazes, the one seeking cures for global pathologies, necessarily turn toward the non-West. (Grovogui 2006a, 4-5)

Indeed, even notions that were developed in and through colonial encounters are portrayed as having developed autonomously without input by others - be it in the form of contribution or contestation. As Grovogui (2006b, 2011b) argues, the issue is not one of a tension between those who seek to guide their practices by the notion of universal human rights and those who resist them. The issue is one of acknowledging that other peoples in other parts of the world also developed notions of human rights.

To recap, postcolonial scholars have been critical of liberal cosmopolitanism not only for (1) seeking to impose particular universals, but also (2) for imposing them arbitrarily, and (3) defining them without due consideration for others' contributions and contestations. As such, the postcolonial critique is not directed against the notion of universals, but the marshaling of particular universalisms in the service of liberal cosmopolitanism.

\section{By way of conclusion}

In the spirit of Burke's resistance to being confined by the boundaries of schools of security theorizing in rethinking the relationship between boundaries and security, I underscored the need for drawing upon the insights of postcolonial critique. I suggested that thinking critically about security, and applying cosmopolitanism to security theorizing should not bracket 'cosmopolitanism' but pay further attention to the postcolonial critique regarding the 'dark side' of liberal cosmopolitanism. For, advancing a cosmopolitan security agenda without interrogating the 'dark side' of liberal cosmopolitanism risks failing to broaden the scope of security beyond one's own community.

I also called for paying further attention to the essence of postcolonial critique, beyond those who utilize postcolonial criticisms of liberal cosmopolitanism to warrant security communitarianism (as with 'Asian values' or 'Dialogue of Civilizations'). As such, 
arguing against security communitarianism involves interrogating: (1) those who seek to order the world in their own image while failing to broaden the scope of security beyond their community (liberal cosmopolitanism); and (2) those who seek to limit the scope of security to one's own community (be it the 'nation-state' or 'civilization').

\section{Notes on contributor}

Pinar Bilgin is an associate professor of International Relations at Bilkent University. She is the author of Regional Security in the Middle East: A Critical Perspective (2005), and The International in Security, Security in the International (forthcoming).

\section{References}

Ayoob, M. 1997. "Defining Security: A Subaltern Realist Perspective." In Critical Security Studies: Concepts and Cases, edited by K. Krause and M. C. Williams, 121-146. London: UCL Press.

Bhambra, G. K., and R. Shilliam, eds. 2009. Silencing Human Rights: Critical Engagements with a Contested Project. New York: Palgrave Macmillan.

Bigo, D. 2001. "The Möbius Ribbon of Internal and External Securit(ies)." In Identities Borders Orders: Rethinking International Relations Theory, edited by M. E. A. Albert. Minnesota, MN: University of Minnesota Press.

Bilgin, P. 2012. "Civilisation, Dialogue, Security: The Challenge of Post-Secularism and the Limits of Civilisational Dialogue." Review of International Studies 38, 1099-1115. doi:10.1017/ S0260210512000496.

Bilgin, P. 2014. "Dialogue of Civilizations: A Critical Security Studies Perspective." Perceptions XIX, 9-24.

Booth, K. 2007. Theory of World Security. Cambridge: Cambridge University Press.

Brown, C. 1988. "The Modern Requirement? Reflections on Normative International Theory in a Post-Western World." Millennium - Journal of International Studies 17, 339-348. doi:10.1177/ 03058298880170020301.

Burke, A. 2001. Fear of Security: Australia's Invasion Anxiety. Edited by D. Bigo, M. Heisler, F. Kratochwil, D. Jacobson, and Y. Lapid, 91-117. Annandale, VA: Pluto Press.

Burke, A. 2007. Beyond Security, Ethics and Violence: War against the Other. New York: Routledge.

Burke, A. 2008. "The End of Terrorism Studies." Critical Studies on Terrorism 1, 37-49. doi:10.1080/17539150701848241.

Burke, A. 2013. "Security Cosmopolitanism." Critical Studies on Security 1, 13-28. doi:10.1080/ 21624887.2013.790194.

Grovogui, S. N. 2005. "The New Cosmopolitanisms: Subtexts, Pretexts and Context of Ethics." International Relations 19, 103-113. doi:10.1177/0047117805050066.

Grovogui, S. N. 2006a. Beyond Eurocentrism and Anarchy: Memories of International Order and Institutions. New York: Palgrave Macmillan.

Grovogui, S. N. 2006b. "Mind, Body, and Gut! Elements of a Postcolonial Human Rights Discourse." In Decolonizing International Relations, edited by B. G. Jones. London: Routledge.

Grovogui, S. N. 2011a. "Looking Beyond Spring for the Season: An African Perspective on the World Order after the Arab Revolt." Globalizations 8, 567-572. doi:10.1080/ 14747731.2011.622868.

Grovogui, S. N. 2011b. "To the Orphaned, Dispossessed, and Illegitimate Children: Human Rights Beyond Republican and Liberal Traditions." Indiana Journal of Global Legal Studies 18: 41-63. doi:10.2979/indjglolegstu.18.1.41.

Jabri, V. 2007. "Solidarity and Spheres of Culture: The Cosmopolitan and the Postcolonial." Review of International Studies 33, 715-728.

Jabri, V. 2013. The Postcolonial Subject: Claiming Politics/Governing Others in Late Modernity. London: Routledge.

Jahn, B. 1998. "One Step Forward, Two Steps Back: Critical Theory as the Latest Edition of Liberal Idealism." Millennium - Journal of International Studies 27, 613-641. doi:10.1177/ 03058298980270030201 . 
Krishna, S. 1993. "The Importance of Being Ironic: A Poscolonial View on Critical International Relations Theory." Alternatives 18, 385-417.

Linklater, A. 1998. The Transformation of Political Community: Ethical Foundations of the Post-Westphalian Era. Columbia: University of South Carolina Press.

Rao, R. 2010. Third World Protest: Between Home and the World. Oxford: Oxford University Press.

Said, E. W. 1975. Beginnings: Intention and Method. New York: Basic Books.

Said, E. W. 2003. "Worldly Humanism v. the Empire-builders." A CounterPunch Special Report: Orientalism 25 Years Later. Accessed 27 May 2015. http://www.counterpunch.org/2003/08/05/ orientalism/.

Walker, R. B. J. 1997. "The Subject of Security.” In Critical Security Studies: Concepts and Cases, edited by K. Krause and M. C. Williams. London: UCL Press.

Wheeler, N. J. 2000. Saving Strangers: Humanitarian Intervention in International Society: Humanitarian Intervention in International Society. Oxford: Oxford University Press. 